Article

\title{
Justice beyond repair: Negative Dialectics and the politics of guilt and atonement
}

\author{
Stephen Cucharo
}

UCLA, Los Angeles, CA 90095, USA.

scucharo@ucla.edu

\begin{abstract}
This article draws out a critical, yet under-appreciated political theme in Adorno's Negative Dialectics, namely his emphasis on guilt and atonement. First, the article assesses how Adorno's Marxism allows him to think justice and guilt beyond the familiar legalistic frame. Second, the article reconstructs Adorno's treatment of guilt as a distinctly political capacity to imagine one's boundedness and indebtedness to others, and the affective engine enabling us to engage in a political ethic distinct from familiar categories of reparation. Third, the article shows how the themes of guilt and atonement give us a more complete picture of Negative Dialectics. This inquiry also intervenes in contemporary debates regarding the political status and emancipatory potential latent within guilt-feelings, and claims Adorno gives us a path forward to imagine the relation between guilt and politics in a novel way.

Contemporary Political Theory (2022) 21, 397-418. https://doi.org/10.1057/s41296021-00528-3; advance online publication 27 September 2021
\end{abstract}

Keywords: guilt; suffering; Adorno; law; dialectics; legalism; justice

Influential interventions in critical theory have directed attention towards guilt as an affective category, one that often polices the boundaries of subjectivity and facilitates obedience to an external moral demand. ${ }^{1}$ Friedrich Nietzsche (2000) and Sigmund Freud (1967, 1989a,b; 1995) are two foundational thinkers for this critical perspective. In Nietzsche's formulation, guilt represents the sharpening of bad conscience, an extreme act of self-abasement before an imposed moral and political law that demands unequivocal obedience. The Freudian perspective, similar in its orientation, takes the Oedipal scene, an inheritance of a primordial act of disobedience, as the site where parental prohibitions are embedded in the superego, reproducing the Nietzschean frame whereby guilt-feelings create a self-punishing subject who feels the weight of demands imposed by external moral limitations. These frameworks, while generative in one sense, are incomplete as a way of understanding guilt as a multifaceted and indeed political affect, one that does not 
simply demand obedience to law and individualized confession, but, on the contrary highlights our interdependence with others, sometimes in defiance of law.

This article proposes that Theodor Adorno's often under-appreciated reflections on guilt and atonement in Negative Dialectics are a way of thinking beyond the familiar linkage of guilt with self-abasement and obedience. Instead, Adorno provides us with an interpretation of guilt as a way of affirming a solidarity with others, in many ways making it a lynchpin of negative dialectical critique. Additionally, this article will suggest that atonement for Adorno amounts to more than a matter of restitution (Honneth, 2009b), recognition (O'Connor, 2004, p. 43), or reparation along the lines of Melanie Klein's reflections on object relations, as Jay Bernstein (2004) suggests. Instead, Adorno supposes that atonement is a critical attempt at political transformation, one spurred on by the solidaristic capacities latent within guilt.

This article begins by reconstructing Adorno's critique of legalism, maintaining that he disentangles guilt, justice and atonement from traditional matters of legal designation and the machinery of 'bourgeois justice', which, as Max Horkheimer and Adorno claim, take on a strictly formal character. Second, this article will elaborate upon the status of guilt in Adorno's corpus, which is the bodily and affective engine that facilitates human solidarity beyond liberal categories. For Adorno, guilt is not a matter of legalistic identification, but a bodily attunement that facilitates an unending practice of making transformative amends through an attentiveness to one's implicatedness in the suffering of others. These claims will provide a foundation to pursue the last contention of this article, which is that atonement and 'doing justice' for Adorno is more than a matter of 'restitution', 'recognition' or 'reparation', but also atoning for the guilt that we share in, deliberately or inadvertently, reproducing the logic and the conditions that made Auschwitz possible, and attempting to transform those conditions. This, as Javier Burdman (2020) rightly notes, is for Adorno 'the only possible moral imperative' after Auschwitz.

Recent scholarship, much of which has followed Hannah Arendt, has called into question the viability of certain kinds of suffering as foundations for political action. ${ }^{2}$ Also following Arendt (2003a, b, 2006), there has been even more skepticism regarding guilt as an affect of a distinctly political, intersubjective, or emancipatory valence. ${ }^{3}$ Building on recent interventions by Claudia Leeb (2018b), this article contributes to the debate on the politics of suffering and the politics of guilt more specifically, and demonstrates how guilt on Adorno's terms has a distinctly political character insofar as it, contra Arendt, fosters a sense of interdependency and critical political engagement rather than self-regard and selfpunishment. Additionally, Adorno's work in Negative Dialectics details a novel conception of transformative justice that has implications for how we might think through the links between affect, suffering and political action. 


\section{Guilt and the Problem of 'Bourgeois Justice'}

Adorno provocatively remarks in Negative Dialectics that 'existence has become a universal guilt context (Schuldzusammenhang)', denoting that human experience is marred by the inescapable and universalizable implicatedness in the suffering of others (Adorno, 2007, p. 372). For political theorists, Adorno's invocation of a discourse of guilt would appear as problematic on its face, insofar as it conjures the fraught discourses of Christian self-abasement and confession, psychoanalytic pathology, or the narrow reduction of a distinctively political problem as a matter of individualized, lawful designation. Yet it is exactly these more recognizable conceptions of guilt, particularly those related to individualized transgression and legality that Adorno wishes to move beyond. Our question is therefore twofold: what are the pitfalls of thinking of guilt in the typical categories of individualized guilt before the law, and how might Adorno aid us in reconceptualizing the specific political valence of guilt outside of traditional, legalist conceptions of justice?

The pursuit of these questions indeed begins at Adorno's critique of the discourse of legality. As the following section will show, Adorno creates a parallel between how appeals to law, legal process and justice function in both bourgeois and fascist society, and how we might think of guilt outside of the rigidity of reified legalistic categories generally. Legalistic thinking does not produce guilt through a legal process, but rather dulls conscience, specifically innate feelings of guilt that facilitate a sense of interdependence, indebtedness and solidarity with others. This will become clearer through a discussion of Horkheimer and Adorno's reflections on 'bourgeois justice' (bürgerliche Gerechtigkeit) in Dialectic of Enlightenment (2002, p. 4).

\section{Commodity Exchange and 'Bourgeois Justice'}

Antonio Vasquez-Arroyo (2016) recently identified a tendency in Adorno scholarship to wrongfully downplay 'his roots in the dialectical legacy of "Hegelian Marxism", in favor of conceptualizing an "ethical Adorno", a proponent of 'ethical modernism' rather than a Marxist critical theorist responsive to historico-political predicaments of power (p. 181). In line with VasquezArroyo's sentiment, recovering the 'Hegelian Marxist' Adorno is crucial if scholars wish to fully understand the character and incisiveness of his critique of traditional conceptions of law and justice in bourgeois society.

Adorno's critique of bourgeois justice takes Marx as its point of departure, specifically Marx's analysis of the commodity form. As Marx begins in Capital, a commodity must be granted a quantifiable identity in the form of exchange value so that it may be 'directly exchangeable with all other commodities' (1990, p. 159). However, what also takes place during this process of quantification is a kind of 
neglect, in which the sensuous characteristics of the commodity are disavowed to make way for a process of abstraction whereby an arbitrary quantitative designation granted to the object takes priority over its qualitative aspects. In other words, for the purposes of exchange, objects are stamped with a detached identity that does not refer to the distinct particularity of that which is being addressed.

What Marx describes is not merely a meditation on 'the mysteries of identity' specific to Marx's age, nor a sterile analysis of how political economy came to understand certain objects as the same or valuable within a particular social totality (Jameson, 1990, p. 23). Rather, through the birth of capitalist commodity exchange, Adorno reads Marx as identifying process of violent reification, in which objects, and indeed individuals, are not seen for the uniqueness or qualitative distinctiveness they embody, but rather come to take on a uniform, fixed and abstract identity that makes them manipulable and exchangeable. If individuals are reduced to 'economic functions' and eventually become nothing more than 'agents or bearers of exchange value', they have no inherent worth outside of the process of exchange (Cook, 2018, p. 23). For Adorno to follow Marx and claim that the 'domination of mankind by the exchange value' is indeed 'universal', the components of exchange, namely abstraction, a false sense of equality and homogenized 'identity-thinking' would need to be reproduced in theory and concrete political practices (Adorno, 2007, p. 178).

It is only upon this historico-political terrain that we can clarify the content and force of Adorno's critique of 'bourgeois justice', which is not grappled with in a sustained way, but can be pieced together in fragments of Dialectic of Enlightenment. Horkheimer and Adorno (2002) claim that 'bourgeois society is ruled by equivalence. It makes dissimilar things comparable by reducing them to abstract quantities' (2002, pp. 4-5). This tendency, however, is not merely apparent as a material phenomenon, but also reproduced in specifically Enlightenment thought, which, Horkheimer and Adorno further claim, has tended to assert that 'anything which cannot be resolved into numbers, and ultimately into one, is illusion' and therefore worthless (2002, pp. 4-5). In the same way that political economy cannot register as meaningful something that cannot be exchangeable, Enlightenment moral theories cannot help but reproduce the same emphasis on quantification, uniformity and universality. The result is that, as Horkheimer and Adorno note, 'the same equations govern justice and commodity exchange' (2002, p. 4). The legal apparatus through which restitution, punishment or reciprocity is to be calculated and administered are corollaries of the 'laws of logic' that were constructed to build a 'unified, scientific order' by Enlightenment rationalists in which all is calculable and manipulable across time and space (2002, p. 63). This means the violent reification of identity-thinking that is perpetuated through exchange is also perpetuated through the institutions that purport to resolve injustices. 
These reflections nevertheless remain ambiguous. What exactly are Horkheimer and Adorno referring to when they inveigh against 'bourgeois justice'? In short, the ideology of legalism more broadly is their target. As Judith Shklar has noted, legalism as posited by neo-Kantians like Hans Kelsen has a tendency to crystalize into 'refined and rigid systems of formal definitions' that isolate 'law completely from the social context within which it exists', instead asserting law as a detached and self-evident 'science' (Shklar, 1986, p. 2). Not only is the distinctly political character of law masked in legalistic thinking, but its inherent tendency towards formalism and uniformity means that legal systems posit 'impersonal rules' as the standards through which justice is supposed to be adjudicated or administered, making justice itself merely a matter of rationalized rule-following rather than an ongoing practice of critical and moral engagement (1986, p. 35).

In legalistic bourgeois justice, a fixed identity of the subject is presupposed, and indeed required if there is to be regularity, conformity and consistency in the application of legal principles. Adorno sees this practice already in the work of Immanuel Kant, who intended to build a uniform and 'properly juridical or legal subject' capable of autonomous self-legislation (Jameson, 1990, p. 19). For Kant, moral reasoning is meant to take on a 'lawful' quality (Jameson, 1990, p. 19), and obligation becomes not a matter of feeling indebted to another and feeling the need to engage in a process of critical restitution, but rather a product of fulfilling a sterile 'external demand' (Shklar, 1986, p. 61). One need only refer to Kant's consistent appeal to the necessary 'purity and strictness' of universally valid moral laws, insulated from our subjective 'wishes and inclinations', to get a sense of how his moral schema also contains a rigid, leveling quality (Kant, 1993, p. 17). All individuals are intended to conform their wills in accordance with an 'objective law of reason' that asserts a universally binding command, which has the function of negating the very possibility for conceptualizing difference and critique (1993, p. 24). This notion of obligation in Kant, which Adorno also equates with a kind of 'moral narcissism', ${ }^{4}$ surrenders the possibility of critical engagement with these fixed universal standards in favor of uncritical obligation.

The character of bourgeois exchange recounted in Marx and the character of 'bourgeois justice' that finds its fullest expression in legalism are similar insofar as they posit abstract principles to make unlike things alike. The commodity is granted an abstract quantity and confronts the market as an exchangeable item. The legal subject's identity is meant to be equally abstract and uniform, which is necessary for it to fit within a totalizing legalistic framework that makes moral and political experience merely a matter of uncritical rule-following. The characteristics of both the legal subject and the commodity are manipulated in order to fit within a hegemonic schema, be it law or political economy. And for Adorno, as long as jurisprudence represents 'the epitome of...a completely consistently structured, dogmatic theory', falsely insisting upon itself as a scientific closed system whereby all moral and political experience is associated with rule-following, it will yield to a 
tendency to uncritically repeat and reproduce judgment (and institutional conditions of judgment) in relation to subjects who are bred to equate moral experience with obedience to a rationalized external demand (Adorno, 2019b, p. 18). This abstract and rigid conception of morality means that bourgeois justice must repress the very possibility of difference, particularity and critical deviation among the objects it has defined. This is how, in History and Freedom, Adorno can assert the only seemingly paradoxical claim that 'justice that amounts to a repetition of sameness' can only be 'unmasked as injustice and perpetual inequality' (Adorno, 2006, p. 170).

This account is fully expressed in Negative Dialectics in the following way:

Law is the primal phenomenon of irrational rationality. In law the formal principle of equivalence becomes the norm; everyone is treated alike. An equality in which differences perish secretly serves to promote inequality...The total legal realm is one of definitions. Its systematic forbids the admission of anything that eludes their closed circle, of anything quod non est in actis. These bounds...turn into real violence as they are sanctioned by law... (2007, p. 309).

Adorno's contention is that the uniformity and calculability of law represses the elements of experience that cannot be neatly categorized and ordered. Bodies of law present themselves as collections of unalterable definition and false conceptions of equality, making them not just compatible with the rigid domination of the 'administered world', but one of its essential components, one that eventually sanctions outright violence.

\section{Law After Auschwitz}

Adorno's assertions related to the continuity between bourgeois and fascist politics are grounded in observations made in his psychoanalytic studies like Guilt and Defense, namely that 'the overwhelming portion of the German population' during the Third Reich, typically considered bystanders, were 'shaped by the moral imagination... of the liberal-bourgeois world, and still internalized a good piece of it' (Adorno, 2010a, p. 53). This made the majority of the population very different from the 'practitioners of violence' who could successfully suppress their conscience entirely, but the fact of their relative acquiescence and willingness to subordinate themselves to a new regime served as a testament to an engrained respect for the supposed morality of rule-following that served as the bedrock of the continuity between bourgeois and fascist life (Adorno, 2010a, p. 53). It is only upon this terrain, a cultivated tendency towards uncritical obedience towards an external moral and political demand, that the Third Reich could have drawn its social legitimacy. 
With this in mind, Adorno links the subject who uncritically submits to legalistic rule-following with the 'potentially fascist individual' outlined in The Authoritarian Personality (Adorno et al, 2019b, , a, p. 1), who demonstrates a 'wish for legality', the hallmark of a dogmatic, thoughtless, 'expropriated conscience' (2019, p. 634). The ideal fascist subject, the thoughtless, machinic individual unable to exercise one's conscience, is for Adorno in effect already the ideal, law-abiding liberal subject. In Hitler's own perverted legalism, uncritical rule-following assumed the same status as a moral imperative, and the tendency that existed in 'bourgeois society' to produce a uniform subject to fit within a totalizing moral schema became intensified in fascist society. The expulsion of difference in bourgeois society takes the form of neglect, disavowal or manipulation, while fascist regimes radicalize this and engage in violent elimination.

Nevertheless, the practical continuity between bourgeois society and fascist society exists well beyond Adorno's insistence that they facilitate rationalized rulefollowing as a supreme and singular moral principle. Both arrangements, through the imposition of external and abstract moral demands, denature the innate sentiments of guilt that would provide an engine for critical engagement with the organization of society. Adorno's Frankfurt School contemporaries approached this very topic, particularly as it relates to guilt, in a cursory fashion that Adorno would address at greater length. Horkheimer, for example, noted in his seminal 'The Jews and Europe' that totalitarian society sought to eliminate 'bad conscience' as the last means of resistance to obedient rule-following (Horkheimer, 1967, p. 36). ${ }^{5}$ Herbert Marcuse noted a similar phenomenon, this time from the perspective of western 'one-dimensional' society, where conscience became 'absolved' into a fully reified apparatus of production and consumption (Marcuse, 1991, p. 79). Their lament that feelings of guilt could be slowly eroded with such grave consequences (i.e., the smoother functioning of apparatuses that reinforce domination), is a testament to guilt's centrality as a means of sensing and experiencing injustice. However, in bourgeois and fascist society, when guilt is strictly associated with the transgression of a rigid, external moral demand, or simply a matter of abstract legalistic designation, it reinforces imposed moral laws themselves rather than providing subjects with a capacity to critique and change them. Yet when guilt is rescued from its connotations of legalistic transgression, and conceptualized as a way of feeling and experiencing failures to acknowledge human interdependence and boundedness, it can retain its critical capacity as a way of producing the possibilities of transformation.

\section{Guilt and Negative Dialectics}

Adorno's interventions on guilt are typically assumed to be of a strictly Freudian character, and primarily situated in psychoanalytic studies like Guilt and Defense 
and The Authoritarian Personality. The former study takes as its aim a thorough elaboration of the visceral defense mechanisms and 'ornate illogic' deployed by 'ordinary' Germans to absolve themselves and others of their implicatedness in the crimes of the Third Reich (Adorno, 2010a, b, p. 76). The sociological link that Adorno makes in Guilt and Defense between nationalist, authoritarian and antisolidaristic feelings, and the desire to repress or externalize feelings of guilt, have a corollary in some observations made in The Authoritarian Personality, insofar as the contributors note that expression of internalized guilt-feelings are connected with 'low-scoring' (less authoritarian) individuals. ${ }^{6}$ Yet these observations in Adorno's psychoanalytic writings provide only a partial view of Adorno's broader work on guilt in his more formal philosophical and political works.

Though Adorno found Freudian categories an indispensable tool in understanding the authoritarian character latent in the bourgeois psyche and fully expressed in the fascist psyche, his towering and intricate contributions to The Authoritarian Personality and Guilt and Defense eclipse a much more critical perspective towards psychoanalysis than is generally recognized. In Minima Moralia, for example, he indicts psychoanalysis as complicit in the culture industry, insofar as it produces 'admonitions to be happy' amidst ongoing human suffering that can be safely placed out of mind (Adorno, 2005a, p. 62). The fundamental problem, Adorno claims, is that the psychoanalysis of Adorno's time relied on the Oedipal scene as the source of guilt-feelings, which in turn allowed very real, perhaps even excessive expressions of guilt, remorse and receptivity to suffering to be waved off as an almost fictitious expression of the Oedipus complex that can be alleviated through therapeutic intervention. ${ }^{7}$ Against the supposedly 'shallow happiness psychoanalysis seeks to recover through its therapeutic "cure" of neuroses", and the perceived tendency of psychoanalysis to write off genuine attentiveness to suffering as neurosis, Adorno wishes to preserve the critical character of the bite of conscience, and the productive identificatory feelings that naturally arise out of our exposure to suffering, feelings that are constantly dismissed or repressed in bourgeois society (Jay, 2020, p. 60). For Adorno, the Oedipal scene as an explanatory framework for guilt-feelings simply loses analytical use because of its tendency to pathologize guilt-feelings or cast them as a function of being too heavily invested in the past. ${ }^{8}$ The analytic intervention can therefore evade or functionally neutralize excessive expressions of conscience as a practice of pathological, punitive self-abasement in a similar way that legalism merely imagines conscience outside of rule-following to be a problem to be repressed or simply unimportant.

Strictly drawing upon Adorno's Freudian heritage can only get scholars so far in understanding how guilt is figured in his broader philosophical corpus. In carving out his own distinct perspective, Adorno very explicitly attempts to rescue guilt from its pathological connotations and legalistic designation. In his 1959 radio address 'The Meaning of Working Through the Past', he critiques the dismissal of 
'guilt complexes' by his contemporaries in reference to the German attempts to come to terms with the recent past:

Psychiatry...maintains that the feeling of guilt is pathological, unsuited to reality, psychogenic, as the analysts call it. The word 'complex' is used to give the impression that the guilt...is actually no guilt at all but rather exists in them, in their psychological disposition: the terribly real past is trivialized into merely a figment of the imagination of those who are affected by it. Or is guilt itself perhaps merely a complex, and bearing the burden of the past pathological, whereas the healthy and realistic person is fully absorbed in the present and its practical goals (2003, p. 5)?

For Adorno, guilt is not to be reflexively transcended or dismissed. He indicts psychoanalysis and psychiatry for pathologizing it and attempting to alleviate it, and he does not draw upon the Oedipal scene as a means of understanding its origins. ${ }^{9}$ This is perceived as an actual avoidance of guilt itself, a failure to meaningfully grapple with the notion that there does exist a real kind of implicatedness in injustice that is not taken seriously if we uncritically follow Freud. Additionally, Adorno claims this posture is compatible with the dictates of the administered world, which has no use for a past, only the present, 'practical' demands of consumer society.

What, then, does Adorno wish to preserve in guilt-feelings? Against legalism or standard Freudian psychoanalysis, guilt for Adorno is an affective capacity that allows us to recognize an indebtedness and boundedness to those who suffer, will suffer, and have suffered in the past, making it temporally multi-dimensional. It enables us to recognize and feel injustice and understand our own implicatedness within an unjust and reified social whole. In reclaiming guilt from legalistic identification and psychoanalytic pathologization, Adorno repurposes it for a new kind of moral-political engagement that is not only cast as reparative justice in response to the violence of commodification and 'identity-thinking', but also produces political possibilities of transforming social life itself.

\section{Survivor's Guilt and the Guilt of Society}

Despite Adorno's psychoanalytic contributions, Adorno's broader and more substantive reflections on guilt specifically are relatively difficult to parse out in his broader corpus. Like Adorno's critique of bourgeois justice, guilt as a category does not receive sustained analytical treatment, and his reflections do not appear to immediately crystalize into a sustained argument. However, upon examination, and in taking reflections from several of his works into account, the thread of guilt can be seen as a crucial lynchpin of the critical method in Negative Dialectics.

Some noticeable references to guilt in Adorno's corpus are autobiographical. His letters to his mother, for example, uncover raw expressions of survivor's guilt for 
having escaped the fate that millions of others had suffered in Europe during his exile. Adorno speaks of 'the injustice of continuing to live, as if one were cheating the dead of light and breath. The sense of such guilt is infinitely powerful in me' (Müller-Doohm, 2005, p. 311). This sentiment does not remain confined to his letters, but also appears with regularity in his lectures and more formal works, communicating the significance of the idea in his philosophy generally. In Metaphysics: Concepts and Problems, after positing the question of whether and how one can live after Auschwitz, he remarks that 'the question has appeared to me...in the recurring dreams which plague me, in which I have the feeling that I am no longer really alive, but am just the emanation of a wish of some victim of Auschwitz' (Adorno, 2001, p. 110).

Though a clear instance of survivor's guilt, Adorno makes of this subjective feeling a more general condition. This is apparent if we reference Adorno's recounting of this same episode in Negative Dialectics, but take note of the fact that rather than discussing survivor's guilt in the first person, he switches to a more indistinct and general third person. ${ }^{10}$ Further on in the Metaphysics lectures, he gestures towards this generalization of survivor's guilt in the following way:

Unless one makes oneself wholly insensitive one can hardly escape the feeling - and by feeling I mean experience which is not confined to the emotional sphere - that just by continuing to live one is taking away that possibility from someone else, to whom life has been denied; that one is stealing that person's life (2001, pp. 112-113).

Guilt here is textured as subjective, but also something that seemingly moves beyond the first person towards a more general affliction. It is not that Adorno simply feels that he is robbing others of life, but he understands that our life within capitalist society solidifies a relation whereby some live at the expense of suffering others, and he registers this indebtedness through guilt.

This movement from the particular to the general is an important step in Adorno's reflections. It allows him to make a connection between the seemingly raw affect generated from our simple acknowledgement that we live at the expense of the suffering other, thereby emphasizing our dependency on those who have and do suffer, and build upon this a more general political problem, a function of capitalism's structural arrangement and its tendency mask this indebtedness through a kind of amnesia and neglect. In Negative Dialectics, he notes:

The guilt of a life which purely as a fact will strangle other life, according to statistics that eke out an overwhelming number of killed with a minimal number of rescued, as if this were provided in the theory of probabilities this guilt is irreconcilable with living. And the guilt does not cease to reproduce itself, because not for an instant can it be made fully, presently conscious (2007, p. 364). 
The fact that we cannot consistently and fully consciously be aware of the fact that we live at the expense of others, both past and present, marks us with the guilt of practicing the 'empty and cold forgetting' that for Adorno is characteristic of bourgeois politics and philosophy (Adorno, 2003, p. 13). By virtue of the fact that it is impossible to live fully conscious of this, we all incur the guilt of not attending to those at present who suffer needlessly by keeping them out of sight. As he puts it bluntly in the History and Freedom lectures, 'a mind that is incapable of looking horror in the face...thereby perpetuates it', thereby highlighting another 'burden of guilt' (Adorno, 2006, p. 7).

This can be clarified in the following way. First, for Adorno, we are afflicted by guilt insofar as many of us live comfortably at the expense of others, both past and present. This is an inevitable function of the administered world, which inflicts significant violence on some so that others may live comfortably, and has never realized its promise to accord the subject 'unabridged autonomy', a guilt that we assume by not living up to our professed ideals of universal freedom. ${ }^{11}$ Adorno is asserting the subject's implicatedness simply by virtue of him or her living in an unjust society and unwittingly perpetuating it. Additionally, there is another kind of guilt at work, because of our consistent failure to recognize this fact, instead buying into the ideological mystifications, or as Adorno claims, 'delusions' that aid in 'papering over' a society's 'guilt and over truth' (2007, p. 368). And the very notion that we unknowingly or knowingly prop up conditions of injustice and suffering make us actively implicated, and indeed guilty in perpetuating the suffering of others. Adorno therefore reserves guilt for when we employ strategies, consciously or unconsciously, in thought or in practice, that help us reconcile ourselves with an unjust world instead of cultivating a resistance to it. But this is not simply a detached designation, it is also an injunction to let oneself feel and recognize one's almost hopeless implicatedness in injustice.

\section{Guilt and Suffering}

It is not sufficient for Adorno to speak of guilt as an acknowledgment that we are indebted to and dependent upon others, and that we share a responsibility to repair the world when it comes under threat. To claim we are guilty of something is not a mere act of description, nor is it necessarily an injunction that we need to feel guilty because of our implicatedness in suffering and its perpetuation. When Adorno is drawing our attention to the feeling of guilt, the somatic experience of guilt, he is claiming we have natural capacities to experience such an affect, but bourgeois society represses these capacities. They are disavowed, neglected or rationalized away, unable to be harnessed for any emancipatory purpose. By making feelings of guilt politically meaningful, Adorno is emphasizing the elements of human experience that are rendered unintelligible under the hegemony of legalistic 'bourgeois justice'. The cold 
calculation of 'reason', the reduction of moral-political engagement to a matter of rulefollowing, makes no room for, or even actively represses, the somatic experience of guilt, pity, remorse, or even something like mourning. ${ }^{12}$

As Adorno would have it, this is a result of the indefensible mind-body dualism at the heart of the bourgeois subject, which privileges sterile rationalization over bodily experience. By highlighting the somatic character of guilt, the task is not to disavow the mind and uphold the primacy of the body, but rather to re-establish the severed and disavowed link between the body and mind and put them back into relationship. Adorno's claim early in Negative Dialectics that 'the need to lend a voice to suffering is the condition of all truth' points us in the direction of what exactly we are to do with guilt (2007, p. 18). In the same way that truth exists in the spaces where there is a disjuncture between the concept and the object to which it refers, moral judgment can be recovered in the affects that cannot be incorporated into the hegemony of identity-thinking. The guilt of not having lent a voice to suffering, which to do fully is impossible on Adorno's terms, is the pivot point through which 'making amends' (wieder gutzumachen) becomes possible (2007, p. 18). This makes guilt a crucial kind of suffering that at once gives us a sense that we are indebted to things and people in the world that suffer violence within a particular historico-political constellation, and thrusts us to make amends for that violence.

In this context, guilt as a legalistic designation, a matter of having found oneself guilty before the law, does not contest or critically engage the content of law itself, nor does it make visible the fact of disavowed dependency and boundedness that Adorno highlights. Adorno's expanded conception of guilt moves beyond mere abstract designation and towards an affective engagement with one's own implicatedness and indebtedness. The claim on the part of bourgeois philosophy that we can exist as rational and autonomous subjects without others is an act of undue disavowal of the world outside of ourselves and our effect on it. Any act of separation between subject and object, rather than an acknowledgement of their mutual and indeterminate dependency, is in effect a 'claim to domination' (Adorno, 2005b, p. 246).

Adorno's general emphasis suffering, as Axel Honneth notes, 'implicitly follows Freud by taking over his idea that neurotic suffering motivates a "need for recovery", , but guilt as a specific kind of suffering takes an altogether different meaning for Adorno than for Freud (2009a, p. 70). Guilt should not be considered mere self-abasement before an externalized moral demand, nor a pathological identification with wrongdoers as it is framed in some circumstances, but rather an act of solidarity with others, one that stems from an acknowledgement that one is bound to a suffering other. Guilt is therefore a kind of suffering and a receptivity to suffering that propels us to transform the world and acknowledge our dependence on it, rather than avoid it, dominate it, or secure obedience to rationalized rules within it. As Adorno remarks towards the end of Guilt and Defense, 'people who desperately tried to escape a feeling of guilt' in the aftermath of war 'are incapable 
of substantive solidarity with any other people' (Adorno, 2010a, p. 182), a 'symptom of an extremely dangerous social-psychological and political potential' (2010a, p. 138). It is this solidarity, an eminently 'cosmopolitan solidarity' (Rensmann, 2012, p. 142), that Adorno wished to rebuild by bringing guilt back into political experience.

\section{Contesting the Politics of Guilt}

Guilt as an affect that facilitates solidarity rather than self-absorption, critique rather than obedience, and the sense of genuine moral indebtedness rather than pathological self-abasement, stands against firmly established tendencies in contemporary political thought. Though Arendt is the most familiar political thinker who denigrates guilt as matter of mere sentimentalism, oftentimes a 'selfregarding' tendency rather than the worldlier and 'political' notion of 'responsibility' (Alweiss, 2003, p. 310), this same skepticism of the political character of guilt has been taken on by more contemporary thinkers. For example, Antonio Vazquez-Arroyo has recently noted that discourses of guilt tend to 'cast a political question in personal terms' and can neglect 'the imperatives of political action' and distinctly political questions of collectivity (2016, p. xviii). As such, there exists a certain anxiety in ascribing to guilt a significant political valence, instead insisting that 'responsibility' implies intersubjectivity and solidarity, whereas guilt implies a matter of personal concern.

This criticism is not a matter of semantics. Arendt forcefully claims that imagining oneself to feel guilty for the suffering of others, particularly if one has not assumed the very direct and immediate suffering of the other, represents a profound moral confusion that in effect amounts to a 'solidarity with the wrongdoers', in this case those who directly participated in Nazi crimes (Arendt, 2003a, b, p. 148). This has even been repeated in certain psychiatric and psychoanalytic literatures, which claimed the sense of survivor's guilt to be a matter of identification with perpetrators, a kind of pathological internalization of a relation of domination. ${ }^{13}$ This grounds Arendt's claims about supposedly confused and unserious 'German youngsters' being 'hysterical' in their 'outbreaks of guilt feeling' in the 1960s upon learning the extent of the crimes of the preceding generation (Arendt, 2006, p. 251).

Though Arendt and Adorno have deeply significant affinities with one another, particularly as it relates to their skepticism directed towards law's capacity to inspire 'human action' (Fine, 2012, p. 171) and in their mutual desire to produce new, 'decentered' and forms of human association and solidarity (Rensmann, 2012, p. 153), their attitudes towards guilt are irreconcilable. Arendt believes guilt to be, as Leeb (2018b) notes, 'private, personal and apolitical' whereas Adorno imagines guilt to inspire and motivate solidarity with those who suffer, and facilitate what Leeb calls 'embodied reflective judgment', the interrelated process by which we 
both think and feel critically (p. 64). Adorno's political thought thereby insists upon the interrelatedness of thinking and feeling, allowing for guilt to be an affective state that spurs on a kind of political and critical reflectiveness. And where Arendt imagines guilt to be relegated as a moral, personal sentiment, and responsibility as eminently political, Adorno implies that there is 'no sharp separation between guilt and responsibility' (Leeb, 2018b, p. 57), and in essence, no sharp division between the moral and the political. On this point it is worth recounting Adorno's last lines from Problems of Moral Philosophy:

In short, whatever we might call morality today goes directly to the question of the organization of the world - one could say: the pursuit of the right life would be the pursuit of the right kind of politics, if such a right kind of politics could be placed in the realm of what is realizable (2010b, p. 262). ${ }^{14}$

Guilt cannot be confined as a matter of personal morality, but rather involves the broad question of social, political and economic structure that makes certain moral experiences possible. More importantly, though, it is the affective receptivity to guilt in relation to human suffering that gives us a sense that political life is not only fraught with indefensible injustice, be it related to class, race, or gender domination, but also that it fails on its own terms to deliver true freedom. Guilt, rather than being self-regarding, signifies one's profound connection to the world as it is and all that's potentially wrong with it, as well as an acknowledgment of one's own inescapable implicatedness in that injustice.

Asserting the interrelated rather than separate character of moral sense and political action does not simply allow us to imagine how guilt can facilitate political engagement. The connection between 'morality today' and 'the organization of the world' brings into consideration the micro element of how we personally live daily life, and how this intimate engagement of our immediate surroundings is politically meaningful, suggesting that there is no break between the reified practices that govern our everyday experiences and the great crimes of the modern era. There is little distance, temporal and otherwise, between our seemingly benign and personal interactions and a stream of global injustice, thus blurring fixed divisions of culpability or innocence. The strictness of Arendt's assertion that one can only 'metaphorically' feel guilty for something we have not directly done, for Adorno, would deny the structural and expansive connection between our unwitting implicatedness in injustice and the fact of its persistence.

\section{The Politics of Atonement}

Contemporary perspectives on global justice, such as those by Robbins (2017) and Rothberg (2019), have sought to develop a language that can clarify the exact character of our embeddedness in transnational systems of inequality and 
domination. Robbins' notion of 'the beneficiary' and Rothberg's term 'the implicated subject' both highlight a relation that is not a direct binary of victim and perpetrator, but a layered situatedness in a relation of domination that gets produced and reproduced through neglected and disavowed participation in, say, global supply chains that solidify the impoverishment of workers across the world, or a reaping the benefits from an unjustifiable hierarchy of racial or sexual domination. Supplementing these immensely illuminating studies with Adorno's reflections allow us to foreground not simply the fact of implicatedness, but also the experience of it, and what a political ethic of atonement might look like in this context. Therefore a revaluation of Adorno's considerations on the topic is not merely a way of refining the way we read his work, but also a way of re-discovering its resonance in an age of increased interdependence.

\section{The 'Performance' of Justice}

Parsing out the significance of Adorno's work on atonement first requires a recapitulation of his diagnosis of bourgeois society. As noted, for Adorno the 'standard structure of society is the exchange form', which is a dynamic that isn't broken, but rather reproduced by bourgeois justice (Adorno, 2005b, p. 248). The subject is fixed as transcendental, objects are determined through a fixed form of conceptualization, and the relation between these two is one of detachment, whereby the subject falsely announces its independence from the object and forgets that it is bound and co-constituted by objects around it. Put simply, under the hegemony of exchange, all relations are determinate and the fixity of the concept that subjects impart to objects is the means by which relations remain determinate and separate. In response, Adorno attempts not to fully break free from this relation, since he pessimistically believes that any moment of transcendence is futile, but rather attempts to find the cracks and contradictions (oftentimes in the form of suffering) that identity-thinking paves over to present itself as natural. Philosophy for Adorno is the space where a dissonance is revealed between what is perceived as fixed and the actual qualitative aspects of the object in question, or the nonidentical elements of an object that defy actual conceptualization. Adorno describes this process as an attempt to 'do justice to reality' (Realitätsgerechtigkeit) (Adorno, 2007, p. 41).

Doing justice in Adorno's sense of the term represents a shift in attention that constitutes an act of resistance to a historically-specific, hegemonic practice of identification. This includes a practice of turning towards the object and recognizing its actual indeterminacy and dependency against the Enlightenment fiction of fixed determinism and superiority of the subject over the object. He writes in Negative Dialectics: 'To yield to the object means to do justice to the object's qualitative moments. Scientific objectification...tends to eliminate qualities and to transform them into measurable definitions. Increasingly, rationality itself is 
equated more mathematico with the faculty of quantification' (2007, p. 43). This is not an attempt at reconciliation, a process by which the non-identical is subsumed into a more advanced concept. Rather, Adorno wishes to destabilize the concept itself and move beyond it while resisting any moment of reconciliation. The nonidentical is not to be instrumentalized, but rather taken as the space that defies instrumentalization and reification (Marasco, 2015, p. 112). That unspeakable suffering exists is a testament to the insufficiencies, failures, and relations of domination that techniques of formal, supposedly humanist reasoning disavow. Suffering itself is an expression of the non-identical.

This labor of the negative dialectic is oftentimes cast as a kind of 'restorative' justice. ${ }^{15}$ We see an example of this through Honneth, who claims Adorno's conception of justice is 'restitutional', in that objects are given their due as being more complex than their concept lets on (Honneth, 2009b, p. 87). Others, such as O'Connor (2004), consider Adorno's commitment to 'doing justice' to be a 'project of recognition, one in which our potential for rationality brings us to the reality that is otherwise distorted in our false forms of consciousness' (p. 43). From a more psychoanalytic vein, Bernstein (2004) has suggested that Negative Dialectics shares deep affinities with Klein's perspectives on guilt and reparation. Bernstein writes that 'Negative Dialectics is structurally the experience of contradiction, the recognition of guilt and the need for reparation, and the reflective activity of reparation - call it critique of the rationalized concept of the concept' (p. 37).

At the same time, restitution, recognition or reparation can imply the possibility of completeness, or even indicate justice as a matter of exchange. One atones for the damage done to the object through a practice of giving something back to it after an act of violence, thereby creating a settlement of damages, a conception of justice that Adorno wished to move beyond. Even the generative linking of Adorno's and Klein's object relations theory undertaken by Bernstein, and more recently by Amy Allen (2021), masks a distinctiveness of Adorno's approach. The Kleinian reparative, which produces a sense of healthy ambivalence towards a love object that one has wronged, no doubt has deep resonance with Adorno's negative dialectic. However, central in Adorno's reflections on guilt is not merely a desire to generate ambivalence, but a desire to consistently produce the possibility of a potentially realizable, future-oriented political state in which things can be thought and done differently. In other words, negative dialectical critique produces moments in which a present reality can be transcended in thought, unearthing a kind of unrealized possibility, but also has a deeply utopian impetus to practically transform an existing material reality. Though guilt for both thinkers can be generative and action-oriented rather than pathologically self-abasing, Adorno's thought retains a productive, infinitely demanding utopian element that Klein lacks. 


\section{Atonement and Transformation}

Discussions of atonement in contemporary political theory oftentimes begin with Arendt's conception of forgiveness, which is framed as a transformative act that releases us from the irreversible character of past deeds and enables participants to 'to begin something new', reformulating a 'web of relations' towards an unforeseeable future (Arendt, 1998, p. 240). Forgiveness, for Arendt, produces distinctly political possibilities through a worldly 'covenant' among individuals that releases us from historical wrongdoing without forgetting it (Knott, 2013 p. 82). It is not an evasion of responsibility, but an acknowledgment of responsibility that 'robs a wrong of its future effectiveness' (Knott, 2013, p. 82).

There are significant parallels with Adorno once again, especially as it relates to their mutual desire to spontaneously produce political possibility amidst injustice. Yet Adorno's frame of critique as atonement does not involve soliciting forgiveness or receiving it, but rather acknowledging one's own implicatedness within a broader system of domination that constantly reproduces itself, and attending to the affective responses that thrust us into critical action. The labor of negative dialectical atonement, though containing a glimmer of hope, never relinquishes a bodily sense of guilt and indeed repulsion in the face of its own implicatedness, something for which Arendt does not account. It is a bodily immersion in the aporetic, a despairing attempt to produce the very possibility of justice and emancipation in moments where it appears as futile.

The labor of working through implicatedness is one of the many theoretical considerations that sets Adorno apart from Arendt, and even apart from Derrida (2001) on the same theme, despite their numerous affinities. ${ }^{16}$ As Peter Dews (2018) notes, for Adorno 'the absolute, non-deconstructible imperative of justice' in the form of bodily attunement to suffering gives Adorno's considerations a materialist engine that constantly produces political engagement in a way that Derrida's reflections on forgiveness do not (p. 121). And contra Derrida, Adorno's political ethic of negation, the practice by which we engage with the dissonances, failures, and insufficiencies of the reified social whole that we inhabit, is concretely spurred on by the suffering of the subject and those upon which the subject is dependent and indebted. As Adorno declares in Negative Dialectics, 'all pain and all negativity' are the 'moving forces of dialectical thinking' (2007, p. 202). And again, in a turn to the body, Adorno claims 'it is the somatic element's survival in knowledge, as the unrest that makes knowledge move, the unassuaged rest that reproduces itself in the advancement of knowledge' (p. 203). Our receptivity towards the suffering of others past, present and future is what gives us the impetus to engage in a practice of 'making amends' for our implicatedness in the specific configuration of power in capitalist modernity. 
Guilt is therefore not only a kind of somatic 'unrest' that makes us attentive towards suffering, it also clearly holds within it a strong and inalienable element of broader responsibility, whereby 'we answer as individuals for what happens in society' (Dews, p. 116). When Adorno reflects on guilt as a way of sensing implicatedness he is identifying the element of moral and political life that not only reveals our indebtedness and connectedness to others, but also gives us the sense that we live at the direct expense of others, thereby provoking an impetus to engage in the painful and despairing labor of atonement through dialectical critique. This is not limited to how we make partial amends for the fact of our implicatedness, but also how we can transform material circumstances by unearthing a set of political possibilities paved over through reification. This particular form of bodily suffering tunes us into the suffering of others and our witting or unwitting implicatedness in that suffering, and the process of 'doing justice' is the continual act of not making reparations within a damaged whole, but atoning for one's implicatedness by attempting to transform and move beyond those relations.

This framing places us in an ironic position to eliminate injustice while simultaneously being aware of its impossibility, tasking us with transcending the conceptual while also being bound to the conceptual. Forced into awareness of the pessimistic doctrine that 'wrong life cannot be lived rightly', the subject is left with a seemingly infinite process of identifying and working through our implicatedness in the suffering of others, in which the guilt we experience is not directed inwards, but rather outwards through unending critical engagement with the conditions that produce the suffering other.

\section{Summary}

The proliferation of scholarship on affect theory and renewed turns towards psychoanalysis has brought back into view the bodily experiences of political life. Yet the status of guilt in critical political literatures remains bound to the basic Nietzschean, Freudian or perhaps Arendtian frame, if it is given sustained treatment at all. An assessment of Adorno's reflections on the subject grants political theorists a means to break free from this perspective and uncover how guilt-feelings can have critical and solidaristic functions and can even spur on distinctly transformative acts of atonement, rather than simply being considered self-regarding, selfabasing, or restrictive. Additionally, this permits us to view Adorno's work in a new light, insofar as it places guilt as a central component Negative Dialectics, a kind of bodily attunement that facilitates an ongoing practice of transformative critical engagement geared towards solidarity with the suffering other.

Increasing global interdependence, particularly in matters of political economy, necessitates the reworking of concepts to account for the experience of our embeddedness within the reified totality of global capitalism. The cemented 
relations of production and exchange characteristic of neoliberal globalization create networks of domination that, in Adorno's phrasing, facilitate relations by which a few live at the expense of the daily suffering of others. The experience of this particular kind of implicatedness, which is a perpetuation of the very kinds of relations of domination that Adorno himself targeted through his own Marxist critique, requires engagement with the set of affects that enable us to sense the pain of our own implicatedness and the suffering of others. This means re-assessing guilt as a distinctly political affect, one that has a multifaceted valence related to critique, but also action.

\section{Acknowledgments}

I would like to extend a very special thanks to Joshua Foa Dienstag, Alex Diones, Rachel Forgash, Scarlett Pinsker and the two anonymous reviewers for their immense assistance with this manuscript. I am also deeply appreciative of the helpful commentary of Kristofer Armstrong, Kye Barker, Ziyaad Bhorat, and Davide Panagia.

Open Access This article is licensed under a Creative Commons Attribution 4.0 International License, which permits use, sharing, adaptation, distribution and reproduction in any medium or format, as long as you give appropriate credit to the original author(s) and the source, provide a link to the Creative Commons licence, and indicate if changes were made. The images or other third party material in this article are included in the article's Creative Commons licence, unless indicated otherwise in a credit line to the material. If material is not included in the article's Creative Commons licence and your intended use is not permitted by statutory regulation or exceeds the permitted use, you will need to obtain permission directly from the copyright holder. To view a copy of this licence, visit http:// creativecommons.org/licenses/by/4.0/.

\section{About the Author}

Stephen Cucharo is a PhD Student in Political Science at the University of California, Los Angeles. His proposed dissertation project is currently entitled 'On Failures of Human Solidarity: Guilt in Modern Political Thought'. He is also one of the current assistant editors at Political Theory.

\section{Notes}

1 See Butler (1997) and Brown (1995), for example.

2 See Leeb (2018a) for a brief elaboration of this problem in political theory.

3 Refer to Schaap (2001) for a sophisticated assessment of Arendt's conception of guilt and its relation to political action. 
4 See Butler (2005, p. 108).

5 Author's translation.

6 See, for example, else Frenkel-Brunswik's contribution 'Dynamic and Cognitive Personality Organization as Seen Through the Interviews' in Adorno et al. (2019b, , a). Expression of conscious, 'open conflict and guilt' for 'feelings of aggression' is found in participants with fewer authoritarian tendencies (p. 450).

7 Adorno's (2005a) puts this in staggering terms: 'It is part of the mechanism of domination to forbid recognition of the suffering it produces, and there is a straight line of development between the gospel of happiness and the construction of camps of extermination so far off in Poland that each of our own countrymen can convince himself that he cannot hear the screams of pain. That is the model of an unhampered capacity for happiness. He who calls it by its name will be told gloatingly by psycho-analysis that it is just his Oedipus complex' (p. 63).

8 This is not to say Adorno does not use the Oedipal scene as an explanatory framework. His work on fascist propaganda, for example, use the Oedipus complex as a way of partially explaining how masses identify with demagogic leaders.

9 Jay (2020) has outlined in detail Adorno's deep skepticism of certain tendencies in psychoanalysis, particularly as they relate to the function of therapeutic intervention.

10 See Adorno (2007, pp. 362-363)

11 The full excerpt reads: 'The more freedom the subject - and the community of subjects - ascribes to itself, the greater its responsibility; and before this responsibility it must fail in a bourgeois life which in practice has never yet endowed a subject with the unabridged autonomy accorded to it in theory. Hence the subject must feel guilty' (Adorno, 2006, p. 221).

12 Refer to Horkheimer and Adorno (2002, p. 179).

13 This is best expressed in chapter one of Leys (2007).

14 Author's translation.

15 See Adorno (2019a, pp. 242; 2010b, p. 254) for examples of his wariness of the term 'restoration'.

16 See Deranty (2006).

\section{References}

Adorno, T.W. (2001) Metaphysics: Concepts and Problems. Stanford: Stanford University Press.

Adorno, T.W. (2003) The meaning of working through the past. In R. Tiedemann (ed.) Can One Live After Auschwitz? A Philosophical Reader. Stanford: Stanford University Press, pp. 3-18.

Adorno, T.W. (2005a) Minima Moralia: Reflections from Damaged Life, Translated by E.F.N. Jephcott. New York: Verso Books

Adorno, T.W. (2005b) On subject and object, Translated by H.W. Pickford. Critical Models: Interventions and Catchwords (pp. 245-258). New York: Columbia University Press

Adorno, T.W. (2006) History and Freedom: Lectures 1964/1965. Cambridge: Polity Press.

Adorno, T.W. (2007) Negative Dialectics. New York: Continuum International Publishing Group.

Adorno, T.W. (2010a) Guilt and Defense: On the Legacies of National Socialism in Postwar Germany,

Edited and Translated by J.K. Olick and A.J. Perrin. Cambridge: Harvard University Press

Adorno, T.W. (2010b) Probleme der Moralphilosophie. Frankfurt: Suhrkamp Verlag.

Adorno, T.W. (2019a) Ontology and Dialectics: 1960-1961. New York: Polity Press.

Adorno, T.W. (2019b) Philosophical Elements of a Theory of Society. Cambridge: Polity Press.

Adorno, T.W., et al. (2019) The Authoritarian Personality. New York: Verso Books. 
Allen, A. (2021) Critique on the Couch: Why Critical Theory Needs Psychoanalysis. New York: Columbia University Press.

Alweiss, L. (2003) Collective guilt and responsibility: Some Reflections. European Journal of Political Theory 2(3): 307-318.

Arendt, H. (1998) The Human Condition. Chicago: University of Chicago Press.

Arendt, H. (2003a) Collective responsibility, Responsibility and Judgment. New York: Schocken Books.

Arendt, H. (2003b) Some questions of moral philosophy, Responsibility and Judgment. New York: Schocken Books.

Arendt, H. (2006) Eichmann in Jerusalem: A Report on the Banality of Evil. Penguin Classics Edition. New York: Penguin Books.

Bernstein, J. (2004) Negative dialectic as fate: Adorno and Hegel. In T. Huhn (ed.) The Cambridge Companion to Adorno. Cambridge: Cambridge University Press, pp. 19-50.

Brown, W. (1995) States of Injury: Power and Injury in Late Modernity. Princeton: Princeton University Press.

Burdman, J. (2020) 'After Auschwitz: Writing history after injustice in Adorno and Lyotard. Contemporary Political Theory. https://doi.org/10.1057/s41296-020-00456-8.

Butler, J. (2005) Giving Account of Oneself. New York: Fordham University Press.

Butler, J. (1997) The Psychic Life of Power: Theories in Subjection. Stanford: Stanford University Press.

Cook, D. (2018) Adorno, Foucault, and the Critique of the West. New York: Verso Books.

Deranty, J.P. (2006) Adorno's other Son: Derrida and the future of critical theory. Social Semiotics 16(3): 421-433. https://doi.org/10.1080/10350330600824011.

Derrida, J. (2001) On forgiveness. In On Cosmopolitanism and Forgiveness. Translated by Mark Dooly and Michael Hughes. New York: Routledge, pp. 27-60.

Dews, P. The idea of hope. Interview by Talita Cavaignac \& Thomas Amorim. New Left Review Issue 112, Jul-Aug 2018, pp. 99-129

Fine, R. (2012) Debating human rights, law, and subjectivity: Arendt, Adorno, and critical theory. In L. Rensmann and S. Gandesha (eds.) Arendt and Adorno: Political and Philosophical Investigations. Stanford: Stanford University Press, pp. 154-172.

Freud, S. (1967) Moses and Monotheism. New York: Vintage Books.

Freud, S. (1989a) The Ego and the Id. New York: W.W. Norton \& Company.

Freud, S. (1989b) Totem and Taboo. New York: W.W. Norton \& Company.

Freud, S. (1995) Civilization and its discontents. In Peter Gay (ed.) The Freud Reader. New York: W.W. Norton \& Company, pp. 722-772.

Honneth, A. (2009a) A Physiognomy of the Capitalist Form of Life: A Sketch of Adorno's Social Theory, Pathologies of Reason: On the Legacy of Critical Theory. New York: Columbia University Press, pp. 54-70.

Honneth, A. (2009b) Performing Justice: Adorno's Introduction to Negative Dialectics, Pathologies of Reason: On the Legacy of Critical Theory. New York: Columbia University Press, pp. 71-87.

Horkheimer, M. and Adorno, T.W. (2002) Dialectic of Enlightenment. Stanford: Stanford University Press.

Horkheimer, M. (1967) Die Juden und Europa, Autoritärer Staat: Die Juden und Europa; Vernunft und Selbsterhaltung; Aufsätze 1939-1941. Amsterdam: De Munter Verlag.

Jameson, F. (1990) Late Marxism: Adorno, or, the Persistence of the Dialectic. New York: Verso Books.

Jay, M. (2020). 'In psychoanalysis nothing is true but the exaggerations': Freud and the Frankfurt School. Splinters in Your Eye: Frankfurt School Provocations. New York: Verso Books. pp. 48-65.

Knott, M.L. (2013) Unlearning with Hannah Arendt, Translated by David Dollenmayer. New York: Other Press.

Leeb, C. (2018a) Rebelling against suffering in capitalism. Contemporary Political Theory 17: 263-282.

Leeb, C. (2018b) The Politics of Repressed Guilt: The Tragedy of Austrian Silence. Edinburgh: Edinburgh University Press. 
Leys, R. (2007) From Guilt to Shame: Auschwitz and After. Princeton: Princeton University Press.

Marasco, R. (2015) The Highway of Despair: Critical Theory After Hegel. New York: Columbia University Press.

Marcuse, H. (1991) One-Dimensional Man: Studies in the Ideology of Advanced Industrial Society. Boston: Beacon Press.

Marx, K. (1990) Capital: A Critique of Political Economy. Vol. I. London: Penguin Classics.

Müller-Doohm, S. (2005) Adorno: A Biography, Translated by R. Livingstone. Cambridge: Polity Press

Nietzsche, F. (2000) On the geneology of morals. In: W. Kaufmann (ed and trans.) The Basic Writings of Nietzsche. New York: The Modern Library. pp. 437-599.

O'Connor, B. (2004) Adorno's Negative Dialectic: Philosophy and the Possibility of Critical Rationality. Cambridge: The MIT Press.

Rensmann, L. (2012) Grounding cosmopolitics: Rethinking crimes against humanity and global political theory with Arendt and Adorno. In L. Rensmann and S. Gandesha (eds.) Arendt and Adorno: Political and Philosophical Investigations. Stanford: Stanford University Press, pp. 154-172.

Robbins, B. (2017) The Beneficiary. Durham: Duke University Press.

Rothberg, M. (2019) The Implicated Subject: Beyond Victims and Perpetrators. Stanford: Stanford University Press.

Schaap, A. (2001) Guilty subjects and political responsibility: Arendt, Jaspers and the resonance of the 'German Question' in politics of reconciliation. Political Studies 49: 749-766.

Shklar, J. (1986) Legalism: Law, Morals, and Political Trials. Cambridge: Harvard University Press.

Vasquez-Arroyo, A. (2016) Political Responsibility: Responding to Predicaments of Power. New York: Columbia University Press.

Publisher's Note Springer Nature remains neutral with regard to jurisdictional claims in published maps and institutional affiliations. 